\title{
Inhibitory effects of a major soy isoflavone, genistein, on human DNA topoisomerase II activity and cancer cell proliferation
}

\author{
YOSHIYUKI MIZUSHINA $^{1,2}$, KAZUAKI SHIOMI ${ }^{1}$, ISOKO KURIYAMA ${ }^{1}$, \\ YOSHIHIRO TAKAHASHI $^{3}$ and HIROMI YOSHIDA ${ }^{1}$ \\ ${ }^{1}$ Laboratory of Food and Nutritional Sciences, Faculty of Nutrition, Kobe Gakuin University, Nishi-ku, Kobe, \\ Hyogo 651-2180; ${ }^{2}$ Cooperative Research Center of Life Sciences, Kobe Gakuin University, Chuo-ku, \\ Kobe, Hyogo 650-8586; ${ }^{3}$ Laboratory of Research and Development, Oguraya Yanagimoto Co. Ltd., \\ Higashi-Nada-ku, Kobe, Hyogo 658-0044, Japan
}

Received April 30, 2013; Accepted June 7, 2013

DOI: 10.3892/ijo.2013.2032

\begin{abstract}
The inhibitory activity of 3 soy isoflavones (daidzein, genistein and glycitein) and their glycosides (daidzin, genistin and glycitin) on mammalian DNA polymerases (pols) and topoisomerases (topos) was investigated. Of the compounds tested, only genistein selectively inhibited human topo II activity and had an $\mathrm{IC}_{50}$ value of $37.5 \mu \mathrm{M}$. These isoflavones had no effect on the activity of human topo I; mammalian pols $\alpha, \beta, \gamma$ and $\kappa$; or on any other DNA metabolic enzyme tested. Thermal transition analysis indicated that genistein did not influence the direct binding to double-stranded DNA. Genistein prevented the proliferation of HCT116 human colon carcinoma cells with an $\mathrm{LD}_{50}$ of $94.0 \mu \mathrm{M}$ and it halted the cell cycle in $\mathrm{G} 2 / \mathrm{M}$ phase. These results suggest that decreases in cell proliferation due to genistein may result from the inhibition of cellular topo II and that genistein, a major soy isoflavone, may be an anticancer food component. The relationship between the structures and these bioactivities of soy isoflavones is discussed.
\end{abstract}

Correspondence to: Dr Yoshiyuki Mizushina, Laboratory of Food and Nutritional Sciences, Faculty of Nutrition, Kobe Gakuin University, Nishi-ku, Kobe, Hyogo 651-2180, Japan

E-mail: mizushin@nutr.kobegakuin.ac.jp

Abbreviations: pol, DNA polymerase (E.C.2.7.7.7); topo, DNA topoisomerase; dsDNA, double-stranded DNA; dTTP, 2'-deoxythymidine-5'-triphosphate; DMSO, dimethyl sulfoxide; EDTA, ethylenediaminetetraacetic acid; BSA, bovine serum albumin; SDS, sodium dodecyl sulfate; EtBr, ethidium bromide; ssDNA, singlestranded DNA; $\mathrm{LD}_{50}, 50 \%$ lethal dose, DS, Discovery Studio; $\mathrm{IC}_{50}$, $50 \%$ inhibitory concentration; Tm, melting temperature; Clog $\mathrm{P}$, calculated $\log \mathrm{P}$

Key words: soy isoflavones, genistein, DNA topoisomerase II, enzyme inhibitor, cancer cell proliferation, cell cycle arrest, anticancer

\section{Introduction}

Cancer is a major public health problem worldwide. Epidemiologic and animal studies indicate that vegetables and fruits with chemopreventive natural products, alone or in combination with others, are associated with a reduced risk of cancer development $(1,2)$. For more than 15 years, we have been screening natural phytochemical products in vegetables and fruits for inhibitors of DNA metabolic enzymes, primarily mammalian DNA polymerases (pols) and human DNA topoisomerases (topos).

Pols (DNA-dependent DNA polymerases, E.C. 2.7.7.7) catalyze deoxyribonucleotide addition to the 3 -hydroxyl terminus of primed double-stranded DNA (dsDNA) molecules (3). The human genome encodes at least 15 pols that function in cellular DNA synthesis $(4,5)$. Eukaryotic cells contain 3 replicative pols $(\alpha, \delta$ and $\varepsilon$ ), one mitochondrial pol $(\gamma)$, and at least 11 non-replicative pols $[\beta, \zeta, \eta, \theta, \mathrm{\iota}, \kappa, \lambda, \mu, v$, terminal deoxynucleotidyl transferase (TdT) and REV1] (6,7). Pols have a highly conserved structure and their overall catalytic subunits show little variance among species. Conserved enzyme structures are usually preserved over time because they perform important cellular functions that confer evolutionary advantages. On the basis of sequence homology, eukaryotic pols can be divided into 4 main families: A, B, X and Y (6). Family A includes mitochondrial pol $\gamma$ as well as pols $\theta$ and $v$. Family B includes pol $\zeta$ and the 3 replicative pols $\alpha, \delta$ and $\varepsilon$. Family $\mathrm{X}$ is comprised of TdT and pols $\beta, \lambda$ and $\mu$. Family $\mathrm{Y}$ includes pols $\eta, \mathrm{t}$ and $\kappa$ in addition to REV1.

Topos are nuclear enzymes that alter the DNA topology required for the replication, transcription, recombination, and segregation of daughter chromosomes (8). Eukaryotic cells have 2 types of topos, I and II. Topo I catalyzes the passage of the DNA strand through a transient single-strand break in the absence of any high-energy cofactor. Topo II, in contrast, catalyzes the passage of DNA double strands through a transient double-strand break in the presence of ATP.

Selective inhibitors of pols and topos are considered potentially useful anticancer, antiviral, antiparasitic and antipregnancy agents because some are known to suppress human cancer and 
normal cell proliferation and are cytotoxic (9-11). We screened soybean isoflavones for these inhibitors. Legumes, particularly soybeans, are the richest sources of isoflavones in the human diet. Studies of soy isoflavones in populations that regularly consume soy protein indicate that such populations have a relatively low incidence of breast cancer and other common cancers. This is because soy protein influences sex hormone metabolism and biological activity through intracellular enzymes, protein synthesis, growth factor actions, malignant cell proliferation, cell differentiation and angiogenesis (12). Soy isoflavones also have some important health-enhancing properties such as prevention of certain cancers (13), lowering the risk of cardiovascular diseases (14) and improvement of bone health (15). In soybeans, isoflavones are present as glycosides (bound to a sugar molecule). Fermentation or digestion of soybeans or soy products results in the release of the sugar molecule from the isoflavone glycoside, leaving an isoflavone aglycone. The primary aglycones of soy isoflavones are daidzein, genistein and glycitein, while the isoflavone glycosides are daidzin, genistin and glycitin (Fig. 1).

The purpose of this study was to find novel bioactivities of these 6 soy isoflavones. We investigated whether these compounds inhibit DNA metabolic enzymes such as pols and topos, or cellular proliferation processes such as DNA replication of human large intestine cancer cells (HCT116). It is possible that soy isoflavones have anticancer activity.

\section{Materials and methods}

Materials. Six soy isoflavones, daidzein (1), daidzin (2), genistein (3), genistin (4), glycitein (5) and glycitin (6), were purchased from Sigma-Aldrich Inc. (St. Louis, MO, USA; Fig. 1). The compounds, purified using HPLC, were of analytical grade. A chemically synthesized DNA template, poly(dA), was purchased from Sigma-Aldrich Inc. and a customized oligo(dT $)_{18}$ DNA primer was produced by Sigma-Aldrich Japan K.K. (Hokkaido, Japan). Radioactive nucleotide $\left[{ }^{3} \mathrm{H}\right]$-labeled 2'-deoxythymidine-5'-triphosphate (dTTP; $43 \mathrm{Ci} / \mathrm{mmol}$ ) was obtained from Moravek Biochemicals Inc. (Brea, CA, USA). Supercoiled pBR322 plasmid dsDNA was obtained from Takara Bio Inc. (Kyoto, Japan). All other reagents were analytical grade and were obtained from Nacalai Tesque Inc. (Kyoto, Japan).

Enzymes. Pol $\alpha$ was purified from calf thymus by immunoaffinity column chromatography, as described by Tamai et al (16). Recombinant rat pol $\beta$ was purified from Escherichia coli $\mathrm{JMp} \beta 5$, as described by Date et al (17). Human pol $\gamma$ catalytic gene was cloned into pFastBac. The histidine-tagged enzyme was expressed using the BACTO-BAC HT Baculovirus Expression System, according to the supplier's instructions (Life Technologies, Frederick, MD) and was purified using ProBond resin (Invitrogen Japan, Tokyo, Japan) (18). Human pols $\delta$ and $\varepsilon$ were purified by nuclear fractionation of human peripheral blood cancer cells (Molt-4) using the second subunit of pol $\delta$ and $\varepsilon$-conjugated affinity column chromatography, respectively (19). A truncated form of human pol $\eta$ (residues 1-511) tagged with His6 at its C-terminal was expressed in E. coli cells and was purified as described by Kusumoto et al (20). A recombinant mouse pol $\iota$ that was tagged with His6 at its C-terminal was expressed by E. coli and purified by Ni-NTA column chro-

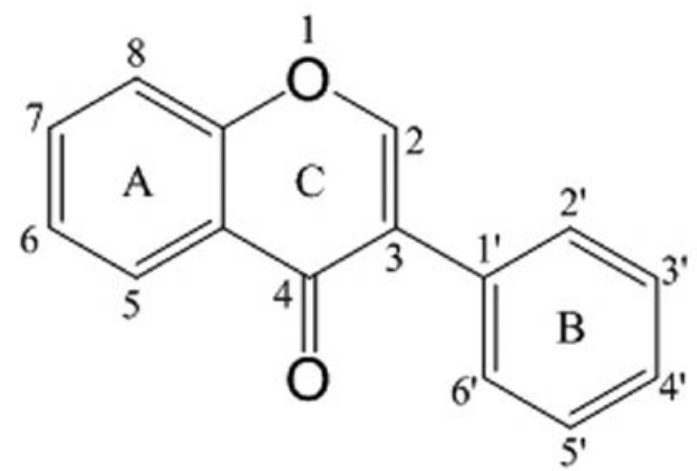

Isoflavone backbone

\begin{tabular}{lcccc}
\hline & 5 & 6 & 7 & 4 \\
\hline Daidzein(1) & $\mathrm{H}$ & $\mathrm{H}$ & $\mathrm{OH}$ & $\mathrm{OH}$ \\
Daidzin (2) & $\mathrm{H}$ & $\mathrm{H}$ & $\mathrm{O}-\mathrm{Glc}$ & $\mathrm{OH}$ \\
Genistein (3) & $\mathrm{OH}$ & $\mathrm{H}$ & $\mathrm{OH}$ & $\mathrm{OH}$ \\
Genistin(4) & $\mathrm{OH}$ & $\mathrm{H}$ & $\mathrm{O}-\mathrm{Glc}$ & $\mathrm{OH}$ \\
Glycitein (5) & $\mathrm{H}$ & $\mathrm{CH}_{3} \mathrm{O}$ & $\mathrm{OH}$ & $\mathrm{OH}$ \\
Glycitin (6) & $\mathrm{H}$ & $\mathrm{CH}_{3} \mathrm{O}$ & $\mathrm{O}-\mathrm{Glc}$ & $\mathrm{OH}$ \\
\hline
\end{tabular}

Figure 1. Structure of soy isoflavones. Daidzein (1), daidzin (2), genistein (3), genistin (4), glycitein (5), and glycitin (6). Glc: glucosyl.

matography (unpublished data). A truncated form of pol $\kappa$ (residues 1-560) with 6X His-tags attached at the C-terminus was overproduced in $E$. coli and purified as described by Ohashi et al (21). Recombinant human His-pol $\lambda$ was overexpressed in $E$. coli and purified according to a method described by Shimazaki et al (22). Recombinant human His-pol $\mu$ was overexpressed in E. coli BL21 and purified using Glutathione Sepharose $^{\mathrm{TM}}$ 4B (GE Healthcare Bio-Science Corp., Piscataway, NJ, USA) column chromatography using the same method as for pol $\lambda$ (22). Calf TdT, T7 RNA polymerase, T4 polynucleotide kinase, and Bovine pancreas deoxyribonuclease I were purchased from Takara Bio Inc. (Kyoto, Japan). Purified human placenta topos I and II were purchased from TopoGen Inc. (Columbus, OH, USA).

Measurement of pol activity. Reaction mixtures for calf pol $\alpha$ and rat pol $\beta$ have been described previously $(23,24)$; those for pol $\gamma$ and for pols $\delta$ and $\varepsilon$ were as described by Umeda et al (18) and Ogawa et al (25), respectively. Reaction mixtures for pols $\eta, \mathrm{\iota}$ and $\kappa$ were the same as for pol $\alpha$ and those for pols $\lambda, \mu$ and TdT were the same as for pol $\beta$. For the pol reactions, poly $(\mathrm{dA}) / \mathrm{oligo}(\mathrm{dT})_{18}(\mathrm{~A} / \mathrm{T}, 2 / 1)$ and $\mathrm{dTTP}$ were used as the DNA template-primer substrate and nucleotide (dNTP; 2'-deoxynucleoside-5'-triphosphate) substrate, respectively. For TdT reactions, oligo $(\mathrm{dT})_{18}\left(3^{\prime}-\mathrm{OH}\right)$ and dTTP were used as the DNA primer substrate and nucleotide substrate, respectively.

Soy isoflavone compounds 1-6 were dissolved in distilled dimethyl sulfoxide (DMSO) to various concentrations and 
sonicated for $30 \mathrm{sec}$. Then, $4 \mu \mathrm{l}$ aliquots were mixed with $16 \mu \mathrm{l}$ of each enzyme (0.05 units) in $50 \mathrm{mM}$ Tris- $\mathrm{HCl}$ at $\mathrm{pH} 7.5$ that contained $1 \mathrm{mM}$ dithiothreitol, $50 \%$ glycerol (by vol), and $0.1 \mathrm{mM}$ ethylenediaminetetraacetic acid (EDTA). The mixtures were maintained at $0^{\circ} \mathrm{C}$ for $10 \mathrm{~min}$. Next, $8 \mu \mathrm{l}$ of each inhibitor-enzyme mixture was added to $16 \mu \mathrm{l}$ of enzyme standard reaction mixture and incubated at $37^{\circ} \mathrm{C}$ for $60 \mathrm{~min}$. The activity in samples without inhibitors was considered to be $100 \%$ and the activity was determined for each inhibitor concentration relative to the uninhibited activity. One unit of pol activity was defined as the amount of each enzyme that catalyzed the incorporation of $1 \mathrm{nmol}$ dTTP into synthetic DNA template-primers in $60 \mathrm{~min}$ at $37^{\circ} \mathrm{C}$ and under normal reaction conditions $(23,24)$.

Measurement of topo activity. The catalytic activity of topo I was determined by detecting supercoiled plasmid DNA (form I) in its nicked form (form II) (26). The topo I reaction was performed in a $20 \mu \mathrm{l}$ reaction mixture that contained 10 mM Tris- $\mathrm{HCl}$ (pH 7.9), pBR322 DNA (250 ng), $1 \mathrm{mM}$ EDTA, $150 \mathrm{mM} \mathrm{NaCl}, 0.1 \%$ bovine serum albumin (BSA), $0.1 \mathrm{mM}$ spermidine, $5 \%$ glycerol, $2 \mu \mathrm{l}$ of one of the 6 test compounds 1-6 dissolved in DMSO, and 2 units of topo I. The catalytic activity of topo II was analyzed in the same manner, except the reaction mixture contained $50 \mathrm{mM}$ Tris- $\mathrm{HCl}$ (pH 8.0), $120 \mathrm{mM} \mathrm{KCl,} 10 \mathrm{mM} \mathrm{MgCl}_{2}, 0.5 \mathrm{mM}$ ATP, $0.5 \mathrm{mM}$ dithiothreitol, supercoiled pBR322 DNA (250 ng), and 2 units of topo II (26). The reaction mixtures were incubated at $37^{\circ} \mathrm{C}$ for $30 \mathrm{~min}$, followed by digestion with $1 \%$ sodium dodecyl sulfate (SDS) and $1 \mathrm{mg} / \mathrm{ml}$ proteinase $\mathrm{K}$. After digestion, $2 \mu \mathrm{l}$ loading buffer, consisting of 5\% sarkosyl, $0.0025 \%$ bromophenol blue, and $25 \%$ glycerol, was added. To study the binding of enzymes to DNA based on mobility shifts, the same procedure was followed, but SDS denaturation and proteinase $\mathrm{K}$ digestion were omitted. The mixtures were subjected to $1 \%$ agarose gel electrophoresis in Tris/borate/EDTA buffer. Agarose gel was stained with ethidium bromide (EtBr) and the DNA band shifts from form I to form II by topos I and II were detected using an enhanced chemiluminescence detection system (Perkin-Elmer Life Sciences Inc., Waltham, MA, USA). Zero-D scan (Version 1.0, M \& S Instruments Trading Inc., Osaka, Japan) was used for densitometric quantitation.

Other enzyme assays. Standard assays were used according to the manufacturer's instructions to measure the activities of T7 RNA polymerase, mouse IMP dehydrogenase (type II), T4 polynucleotide kinase, and bovine deoxyribonuclease I, as described by Nakayama and Saneyoshi (27), Mizushina et al (28), Soltis and Uhlenbeck (29) and Lu and Sakaguchi (30), respectively.

Thermal transition of DNA. Thermal profiles of the transition of dsDNA to single-stranded DNA (ssDNA) with or without genistein were obtained using a spectrophotometer (UV-2500, Shimadzu Corp., Kyoto, Japan) equipped with a thermoelectric cell holder, as described previously (31). Calf thymus DNA $(6 \mu \mathrm{g} / \mathrm{ml})$ was dissolved in $0.1 \mathrm{M}$ sodium phosphate buffer (pH 7.0) that contained 1\% DMSO. The solution temperature was equilibrated at $75^{\circ} \mathrm{C}$ for $10 \mathrm{~min}$, and then increased by $1^{\circ} \mathrm{C}$ at 2-min intervals for each measurement point. Any change in the absorbance of the compound at each temperature point was automatically subtracted from that of the combined absorbance of the DNA and the compound by the spectrophotometer.

Cell culture and measurement of cancer cell viability. A human colon carcinoma cell line, HCT116, was obtained from the American Type Culture Collection (Manassas, VA, USA). HCT116 cells were cultured in McCoy's 5A medium supplemented with $10 \%$ fetal bovine serum, penicillin $(100 \mathrm{U} / \mathrm{ml})$, and streptomycin $(100 \mu \mathrm{g} / \mathrm{ml})$ at $37^{\circ} \mathrm{C}$ in a humid atmosphere of $5 \% \mathrm{CO}_{2} / 95 \%$ air. For the cell viability assay, cells were plated at $1 \times 10^{4}$ into each well of a 96-well microplate with various concentrations of genistein. Cell viability was determined by the WST-1 assay (32).

Cell cycle analysis. Cellular DNA content for cell cycle analysis was determined as follows: aliquots of 3x10 $0^{5}$ HCT116 cells were added to a $35-\mathrm{mm}$ dish and incubated with a medium that contained genistein $[94.0 \mu \mathrm{M}$ based on the $50 \%$ lethal dose $\left(\mathrm{LD}_{50}\right)$ value] for $24 \mathrm{~h}$. Cells were then washed with ice-cold PBS 3 times by centrifugation, fixed with $70 \%(\mathrm{v} / \mathrm{v})$ ethanol, and stored at $-20^{\circ} \mathrm{C}$. DNA was stained with PI (3,8-diamino-5-[3-(diethylmethylammonio)propyl]-6-phenylphenanthridinium diiodide) staining solution for at least $10 \mathrm{~min}$ at room temperature in the dark. Intensity of fluorescence was measured using a FACSCanto flow cytometer in combination with FACSDiVa software (Becton-Dickinson Co., Franklin Lakes, NJ, USA).

Computationalanalysis. The molecular structures of compounds were constructed using Discovery Studio (DS) 3.5 modeling software (Accelrys Inc., San Diego, CA, USA). Energy minimization was achieved using a salvation model and was calculated by the GBSW (Generalized Born with simple switching) parameter using the Minimization and Dynamics protocols contained within DS. The calculation used a CHARMm (Chemistry at HARvard Macromolecular Mechanics) force-field.

\section{Results}

Effect of soy isoflavones on the activity of mammalian pols. The inhibitory activity of each soy isoflavone toward mammalian pols was investigated using calf pol $\alpha$, rat pol $\beta$, human pol $\gamma$, and human pol $\kappa$. Pols $\alpha, \beta, \gamma$ and $\kappa$ were used as representatives of the B, X, A, and Y families of pols, respectively $(6,7)$. Assessment of the relative activity of each pol at a set concentration $(100 \mu \mathrm{M})$ of the 6 soy isoflavones showed that none of the compounds had any effect on pol inhibition, as no compound resulted in $<90 \%$ relative activity of the 4 pols (Fig. 2). These results suggest that soy isoflavones do not influence the activities of mammalian pol species. When activated DNA (bovine deoxyribonuclease I-treated DNA) was used as the DNA template-primer substrate instead of synthesized DNA [poly $(\mathrm{dA}) /$ oligo $\left.(\mathrm{dT})_{18}(\mathrm{~A} / \mathrm{T}=2 / 1)\right]$ and dNTP was used as the nucleotide substrate instead of dTTP, the inhibitory effects of these compounds did not change (data not shown).

Effects of soy isoflavones on the activity of human topos I and II. The inhibitory effects of each soy isoflavone were examined against human topos I and II, which have ssDNA and dsDNA 




Figure 2. Effect of soy isoflavones (1-6) on the activity of mammalian pols. Each compound (100 $\mu \mathrm{M})$ was incubated with calf pol $\alpha$, rat pol $\beta$, human pol $\gamma$ and human pol $\kappa$. Pol activity is shown as a percentage of enzyme activity in the absence of the compound, which was taken to be $100 \%$. Data are the means \pm SD of 3 independent experiments.

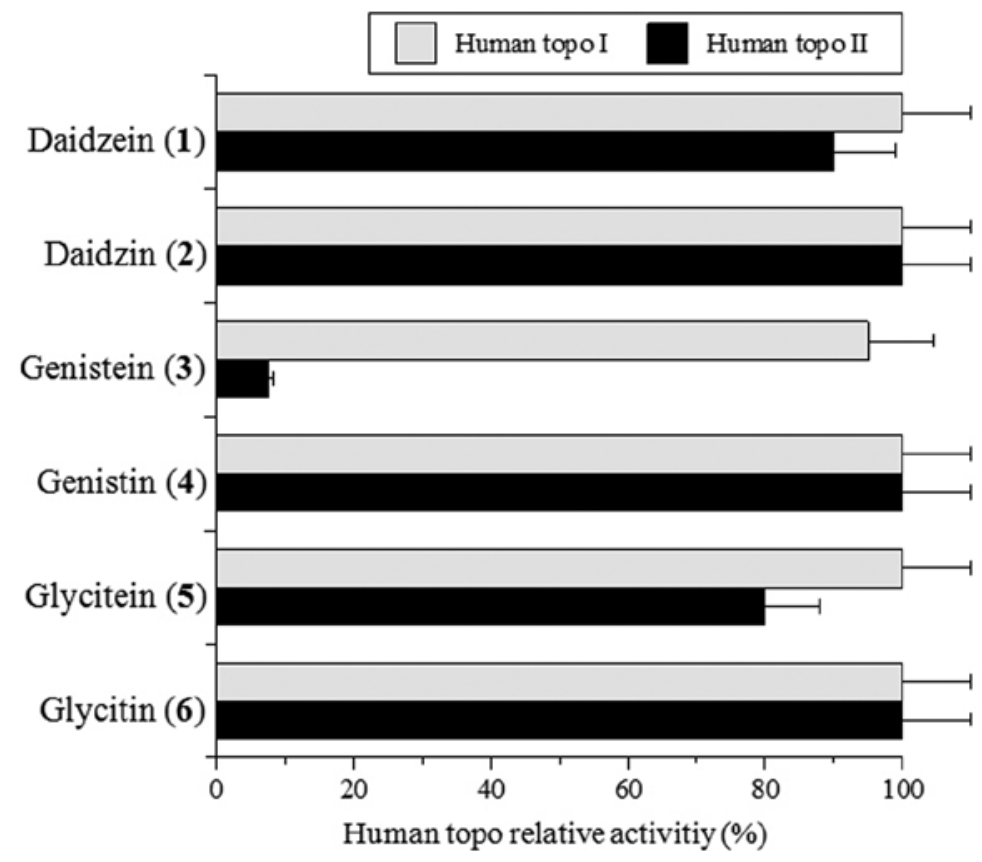

Figure 3. Effect of soy isoflavones (1-6) on the activity of human topos I and II. Each compound (100 $\mu \mathrm{M}$ ) was incubated with topo I (gray bar) and topo II (black bar). Topo activity is shown as a percentage of enzyme activity in the absence of the compound, which was taken to be $100 \%$. Data are the means \pm SD of 3 independent experiments.

nicking activity, respectively (8). None of the soy isoflavones at $100 \mu \mathrm{M}$ influenced topo I nicking activity (Fig. 3). Even at concentration of greater than $100 \mu \mathrm{M}$, these compounds had no effect on topo I activity (data not shown). In contrast, $100 \mu \mathrm{M}$ of genistein (6) completely inhibited the nicking activity of topo II, while the other compounds inhibited topo II to a lesser extent or not at all (Fig. 3). These results suggest that genistein is a potent human topo II inhibitor, but there are no topo I inhibitors among the 6 soy isoflavones tested. Genistein was therefore selected for further study. 
Table I. $\mathrm{IC}_{50}$ values of genistein for the activity of mammalian pols, topos and other DNA metabolic enzymes.

\begin{tabular}{|c|c|}
\hline Enzymes & $\mathrm{IC}_{50}(\mu \mathrm{M})$ \\
\hline \multicolumn{2}{|l|}{$\begin{array}{l}\text { Mammalian pols } \\
\text { (A-family) }\end{array}$} \\
\hline $\begin{array}{l}\text { Human pol } \gamma \\
\text { (B-family) }\end{array}$ & $>200$ \\
\hline Calf pol $\alpha$ & $>200$ \\
\hline Human pol $\delta$ & $>200$ \\
\hline Human pol $\varepsilon$ & $>200$ \\
\hline \multicolumn{2}{|l|}{ (X-family) } \\
\hline Rat pol $\beta$ & $>200$ \\
\hline Human pol $\lambda$ & $>200$ \\
\hline Human pol $\mu$ & $>200$ \\
\hline Calf TdT & $>200$ \\
\hline \multicolumn{2}{|l|}{ (Y-family) } \\
\hline Human pol $\eta$ & $>200$ \\
\hline Mouse pol ı & $>200$ \\
\hline Human pol $\kappa$ & $>200$ \\
\hline \multicolumn{2}{|l|}{ Mammalian topos } \\
\hline Human topo I & $>200$ \\
\hline Human topo II & $37.5 \pm 2.5$ \\
\hline \multicolumn{2}{|l|}{ Other DNA metabolic enzymes } \\
\hline T7 RNA polymerase & $>200$ \\
\hline Mouse IMP dehydrogenase (type II) & $>200$ \\
\hline T4 polynucleotide kinase & $>200$ \\
\hline Bovine deoxyribonuclease I & $>200$ \\
\hline
\end{tabular}

Genistein was incubated with each pol, topo and other DNA metabolic enzymes. Enzyme activity in the absence of the compound was taken to be $100 \%$. Data are the means \pm SD of 3 independent experiments.

Effects of genistein on the activity of mammalian pols, topos and other DNA metabolic enzymes. Genistein did not affect the activity of any of the eleven mammalian pol species tested in vitro (Table I). Genistein inhibited the activity of human topo II with a $50 \%$ inhibitory concentration $\left(\mathrm{IC}_{50}\right)$ value of $37.5 \mu \mathrm{M}$ (Table I).

Genistein had no influence on the activity of other DNA metabolic enzymes such as T7 RNA polymerase, mouse IMP dehydrogenase (type II), T4 polynucleotide kinase, and bovine deoxyribonuclease I (Table I). These results indicate that genistein should be specifically classified as an inhibitor of human topo II.

Influence of genistein on the hyperchromicity of dsDNA. Specific assays were performed to determine whether genistein-induced inhibition resulted from the ability of the compound to bind to DNA or to the enzyme. The interaction of genistein with dsDNA was investigated by studying its thermal transition. To accomplish this, the melting temperature (Tm) of dsDNA in the presence of an excess of genistein $(200 \mu \mathrm{M})$ was measured using a spectrophotometer equipped with a thermoelectric cell holder. As shown in Fig. 4, when a typical

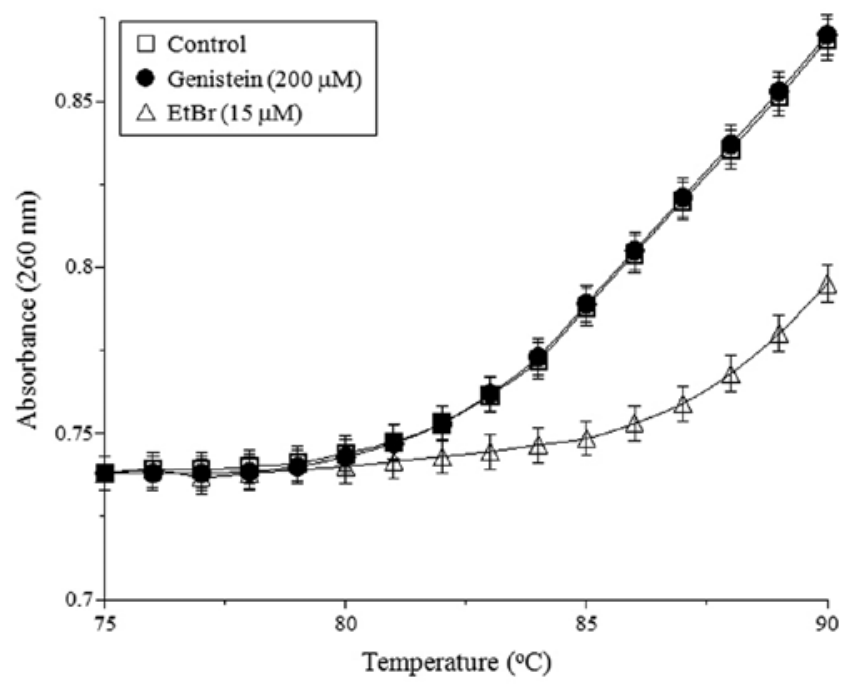

Figure 4. Effect of genistein on the thermal transition of dsDNA. Control (buffer only, open-square), genistein (200 $\mu \mathrm{M}$, closed-circle), and ethidium bromide ( $\mathrm{EtBr}, 15 \mu \mathrm{M}$, open-triangle) were incubated with $6 \mu \mathrm{g} / \mathrm{ml}$ of calf thymus dsDNA in 0.1 M Na-phosphate buffer ( $\mathrm{pH}$ 7.0). Data are the means $\pm \mathrm{SD}$ of 3 independent experiments.

intercalating compound, $\operatorname{EtBr}(15 \mu \mathrm{M})$, was used as a positive control, a clear thermal transition (i.e., Tm) was observed from 75 to $90^{\circ} \mathrm{C}$. However, no such thermal transition was observed when genistein was heated with dsDNA.

The question of whether the inhibitory effect of genistein resulted from non-specific adhesion to human topo II or from its selective binding to specific sites was investigated by determining whether an excessive amount of nucleic acid [poly $(\mathrm{rC})]$ or protein (BSA) prevented the inhibitory effect of genistein. Poly $(\mathrm{rC})$ and BSA had little or no influence on the inhibition of topo II by genistein (data not shown), suggesting that this compound selectively bound to the topo II enzyme molecule. These observations indicate that genistein does not act as a DNA intercalating agent or as a template-primer substrate. Instead, this compound binds directly to topo II and inhibits its activity.

Collectively, these results suggest that genistein may be a potent and specific inhibitor of human topo II. We therefore investigated in more detail whether topo II inhibition by genistein results in decreased human cancer cell proliferation.

Effect of genistein on cultured human cancer cells. Topos have recently emerged as important cellular targets for chemical intervention in the development of anticancer agents. Genistein could therefore be useful in chemotherapy, and thus, we investigated the cytotoxic effect of this compound against the HCT116 human colon carcinoma cultured cell line. As shown in Fig. 5A, $24 \mathrm{~h}$ of treatment with genistein treatment suppressed HCT116 cell growth in a dose-dependent manner, with a 50\% lethal dose $\left(\mathrm{LD}_{50}\right)$ of $94.0 \mu \mathrm{M}$. This $\mathrm{LD}_{50}$ is 2.5 -fold higher than the $\mathrm{IC}_{50}$ for topo II. This suggests that genistein may be able to penetrate the cell membrane and reach the nucleus, where it may inhibit the activity of topo II, which leads to suppression of cell growth.

Next, we analyzed whether genistein affected the cell cycle distribution of compound-treated HCT116 cells. The cell cycle 


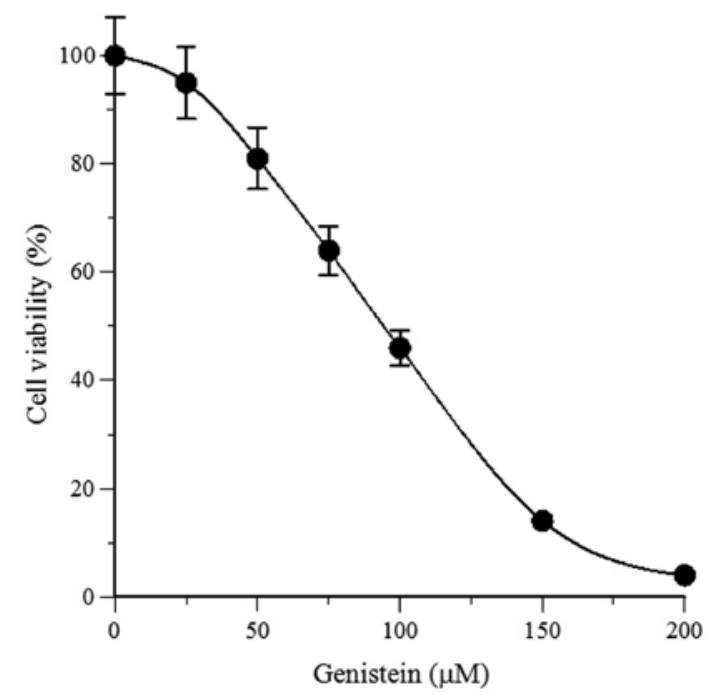

\section{Control}

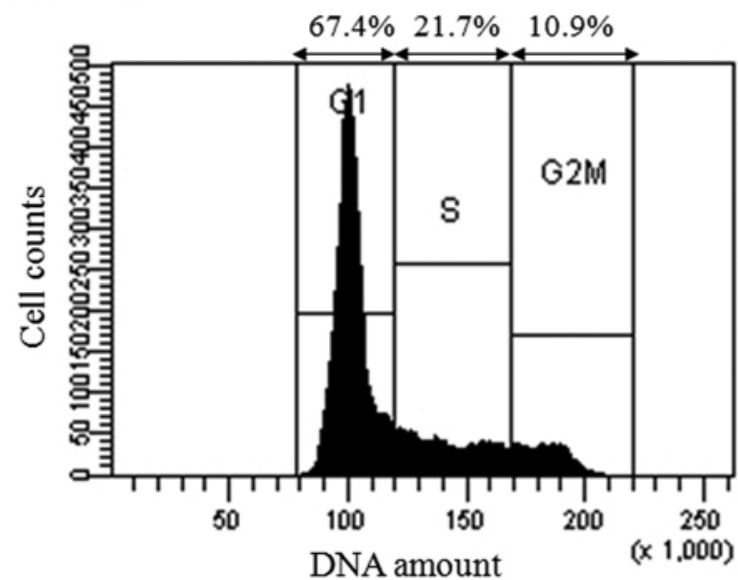

Genistein $(94.0 \mu \mathrm{M})$

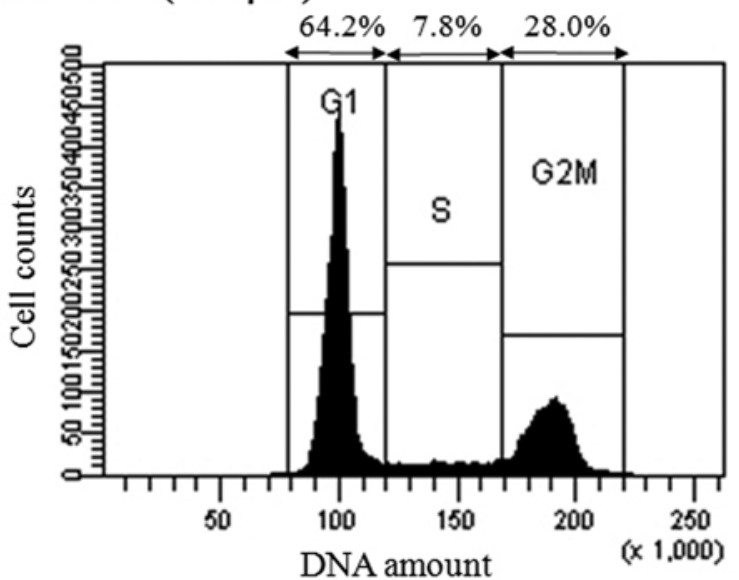

Figure 5. Effect of genistein on cultured HCT116 human colon carcinoma cell growth and cell cycle. (A) Dose-response curve of cell survival rate. The cells were cultured for $24 \mathrm{~h}$ in media containing the indicated concentrations of genistein. Cell proliferation was determined using the WST-1 assay (32). Cell growth inhibition in the absence of the compound was taken to be $100 \%$. Data are the means \pm SD of 5 independent experiments. (B) Cell cycle analysis. Cells were cultured for $24 \mathrm{~h}$ with (right panel) or without (left panel; control) $94.0 \mu \mathrm{M}$ genistein $\left(\mathrm{LD}_{50}\right)$ and were analyzed using flow cytometry. Cell cycle distribution was calculated as the percentage of cells in the G1, S and G2/M phases. All experiments were performed 3 times.

fraction was recorded after $24 \mathrm{~h}$ of treatment with a concentration of genistein equal to its $\mathrm{LD}_{50}$. The ratio of cells in each of 3 phases (i.e., G1, S, and G2/M) in the cell cycle is shown in Fig. 5B. Treatment with genistein significantly increased the population of cells in the G2/M phase (2.57-fold increase of cells in $\mathrm{G} 2 / \mathrm{M}$ phases), did not significantly change the proportion of cells in the G1 phase, and greatly decreased the percentage of cells in the $\mathrm{S}$ phase. Etoposide, which is a classic topo II inhibitor, arrested the cell cycle in the G2/M phase (1.80-fold increase of cells in G2/M phase, data not shown). These results suggest that genistein may be an effective inhibitor of topo II and halts the cell cycle at the G2/M phase.

\section{Discussion}

Soybeans contain the highest concentrations of isoflavones, at 1-3 mg/g, such as daidzein, genistein, glycitein and their corresponding glycosides, such as daidzin, genistin and glycitin, respectively, of foods consumed by humans. According to USDA data (33), total soybean isoflavones consist of $37 \%$ daidzein, $57 \%$ genistein and $6 \%$ glycitein; therefore, the main component of soy isoflavone is genistein. When ingested as part of the diet, genistin is readily converted to its aglycone form, genistein. Genistin is hydrolyzed by removal of the covalently bound glucose to form genistein. Genistein is the form of the compound that is absorbed in the intestine and is responsible for the biological activity of the isoflavone. It was first demonstrated in 2002 that gut microflora play a large role in the conversion of genistin to genistein (34). It was later found that enzymes present in the human small intestine and liver also have the ability to convert the isoflavone. Hydrolysis starts very quickly in the digestive system once genistin is ingested. Conversion begins in the mouth and continues in the small intestine. Moreover, both human saliva and intestinal cell-free extract from mice can completely convert genistin to genistein (34).

The three-dimensional structure of genistein and genistin, from which the energy-minimized compounds 


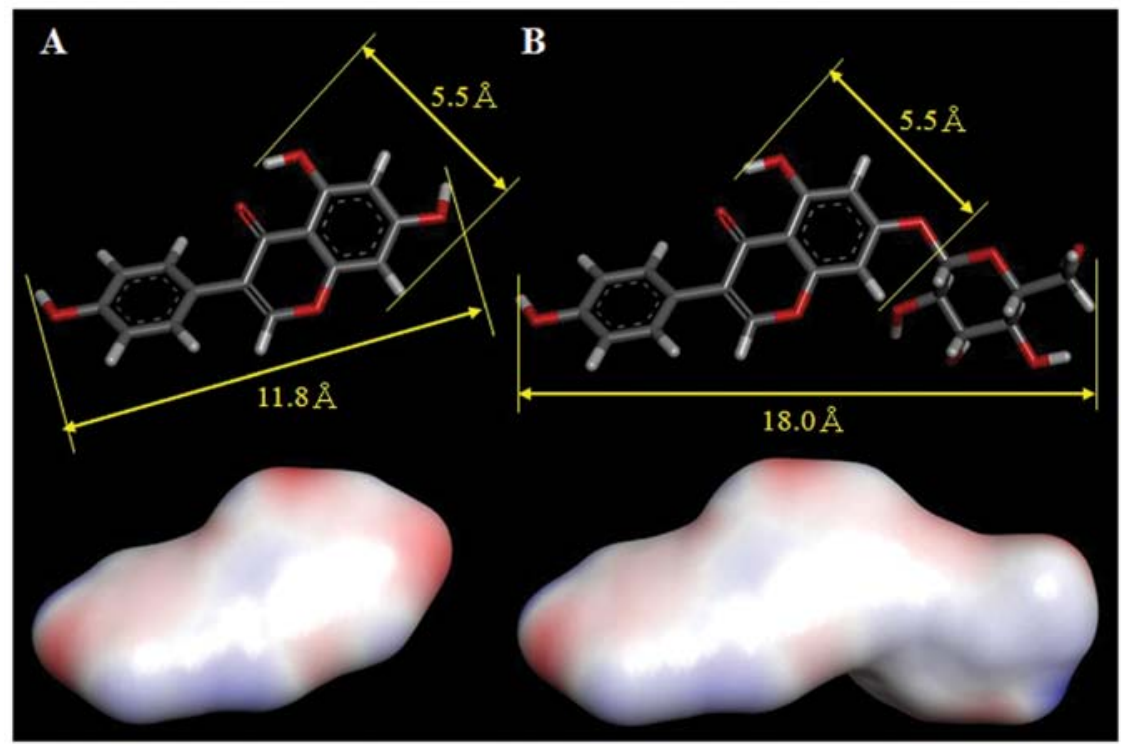

Figure 6. Three-dimensional structure of genistein and genistin. (A) Genistein. (B) Genistin. Upper panels, stick models. The carbon, hydrogen and oxygen atoms of these compounds are indicated in grey, white and red, respectively. Lower panels, electrostatic potentials over molecular surfaces. Blue areas are positively charged, red are negatively charged and white are neutral. The energy-minimized compounds were calculated as described in Materials and methods.

were calculated, were compared. The molecular length and width of these compounds are indicated in the upper panels of Fig. 6. The width of genistein is the same as that of genistin, but the length of genistein and genistin are 11.8 and 16.6 $\AA$, respectively, a 1.4 -fold difference. There is likely an inhibitor binding pocket on the topo II protein surface, and the width and length of this pocket might be approximately 5.5 and $11.8 \AA$, respectively, to accommodate genistein. The calculated $\log \mathrm{P}(\mathrm{C} \log \mathrm{P})$ values (partition coefficients for octanol/water) of genistein and genistin are different $(\mathrm{C} \log \mathrm{P}=3.114 \pm 1.137$ for genistein and $\mathrm{Clog} \mathrm{P}=0.942 \pm 0.912$ for genistin), but these compounds have nearly the same pKa (acid dissociation constant; $\mathrm{pKa}=6.51 \pm 0.20$ for genistein and $\mathrm{pKa}=6.12 \pm 0.20$ for genistin). The molecular length, width, and hydrophobicity (Clog $\mathrm{P}$ and surface area of the functional group negative/positive charges; the lower panels of Fig. 6) of these compounds are likely important for their bioactivity. Genistin is the 7-O- $\beta$-D-glucoside form of genistein and the conjugated glycoside has a molecular length and hydrophobicity that are different from that of the aglycone. Therefore, the aglycone structure (without a sugar) must be important for topo II inhibition. The hydroxyl group in 5-position of B ring of the isoflavone backbone is considered to be the essential structural moiety of genistein (4',5,7-trihydroxyisoflavone) that is responsible for the observed activity. This is because the other soy isoflavone aglycones, daidzein (4',7-dihydroxyisoflavone) and glycitein (4',7-dihydroxy-6-methoxyisoflavone) lack the hydroxyl group had no inhibitory effect of topo II activity (Figs. 1 and 3).

Topo II inhibitors such as adriamycin, amsacrine, ellipticine, saintopin, streptonigrin and terpentecin are intercalating agents that are thought to bind to the DNA molecule directly and subsequently inhibit topo II activity indirectly. These chemicals inhibit the DNA chain-rejoining reactions that are catalyzed by topo II by stabilizing a tight topo II
protein-DNA complex called the 'cleavable complex'. The possibility that genistein also binds to DNA was examined by measuring the Tm of dsDNA and no genistein was found to bind to dsDNA (Fig. 4). Thus, genistein must have inhibited enzyme activity by interacting directly with the enzyme. Topo inhibitors are categorized into 2 classes, 'suppressors', which are believed to interact directly with the enzyme, and 'poisons', which stimulate DNA cleavage and intercalation (35). Genistein may be considered a 'suppressor' of topo functions rather than a conventional poison as this compound does not appear to stabilize topo II protein-DNA covalent complexes. Genistein may therefore be a new type of topo II inhibitor.

Genistein, a major component of soy isoflavones, has many physiological actions such as estrogen action, antioxidation, mutation prevention, anti-infection, and the prevention rehabilitation of heart-cerebrovascular disorders (36-38). This suggests that genistein might be useful for health care applications. In this study, we found that genistein causes human cancer cell cytotoxicity by arresting the cell cycle at the G2/M phase, and that it acts via the inhibition of topo II. Therefore, soy isoflavones containing genistein are food components that have potential for the prevention of cancer and promotion of health.

\section{Acknowledgements}

This study was supported in part by the Ministry of Education, Culture, Sports, Science and Technology, Japan (MEXT)Supported Program for the Strategic Research Foundation at Private Universities, 2012-2016. Y.M. acknowledges Grantsin-Aid for Scientific Research (C) (no. 24580205) from MEXT and the Hyogo Science and Technology Association (Japan). I.K. acknowledges a Grant-in-Aid for Young Scientists (B) (no. 23710262) from MEXT. 


\section{References}

1. Liu RH: Potential synergy of phytochemicals in cancer prevention: mechanism of action. J Nutr 134: 3479S-3485S, 2004

2. Surh YJ: Cancer chemoprevention with dietary phytochemicals. Nature Rev Cancer 3: 768-780, 2003.

3. Kornberg A and Baker TA: DNA Replication. 2nd edition. W.D. Freeman and Co., New York, NY, pp197-225, 1992.

4. Hubscher U, Maga G and Spadari S: Eukaryotic DNA polymerases. Ann Rev Biochem 71: 133-163, 2002.

5. Bebenek K and Kunkel TA: Advances in Protein Chemistry. Yang W (ed). Elsevier, San Diego, CA, pp137-165, 2004.

6. Lange SS, Takata K and Wood RD: DNA polymerases and cancer. Nat Rev Cancer 11: 96-110, 2011.

7. Loeb LA and Monnat RJ Jr: DNA polymerases and human disease. Nature Rev Genet 9: 594-604, 2008.

8. Wang JC: DNA topoisomerases. Ann Rev Biochem 65: 635-692, 1996.

9. Liu LF: DNA topoisomerase poisons as antitumor drugs. Ann Rev Biochem 58: 351-375, 1989.

10. Sakaguchi K, Sugawara F and Mizushina Y: Inhibitors of eukaryotic DNA polymerases. Seikagaku 74: 244-251, 2002 (In Japanese).

11. Berdis AJ: DNA polymerases as therapeutic targets. Biochemistry (Moscow) 47: 8253-8260, 2008.

12. Heber D: Plant Foods and Phytochemicals in human health Berdanier CD, Dwyer JT, Feldman EB (eds). CRC Press, pp176-181, 2008.

13. Barnes $\mathrm{S}$ and Messina $\mathrm{M}$ : The role of soy products in reducing cancer risk. J Natl Cancer Inst 83: 541-546, 1991

14. Anderson JM, Johnstone BM and Cook-Newell ME: Metaanalysis of the effects of soy protein intake on serum lipids. N Engl J Med 333: 276-282, 1995.

15. Bahram HA, Alekel L, Hollis BW, Amin D, StacewiczSapuntzakis M, Guo P and Kukreja SC: Dietary soybean proteins prevent bone loss in an ovariectomized rat model of osteoporosis. J Nutr 126: 161-167, 1996.

16. Tamai K, Kojima K, Hanaichi T, Masaki S, Suzuki M, Umekawa $\mathrm{H}$ and Yoshida S: Structural study of immunoaffinitypurified DNA polymerase $\alpha$-DNA primase complex from calf thymus. Biochim Biophys Acta 950: 263-273, 1988.

17. Date T, Yamaguchi M, Hirose F, Nishimoto Y, Tanihara K and Matsukage A: Expression of active rat DNA polymerase $\beta$ in Escherichia coli. Biochemistry 27: 2983-2390, 1988.

18. Umeda S, Muta T, Ohsato T, Takamatsu C, Hamasaki N and Kang D: The D-loop structure of human mtDNA is destabilized directly by 1-methyl-4-phenylpyridinium ion $\left(\mathrm{MPP}^{+}\right)$, a parkinsonism-causing toxin. Eur J Biochem 267: 200-206, 2000.

19. Oshige M, Takeuchi R, Ruike R, Kuroda K and Sakaguchi K: Subunit protein-affinity isolation of Drosophila DNA polymerase catalytic subunit. Protein Expr Purif 35: 248-256, 2004

20. Kusumoto R, Masutani C, Shimmyo S, Iwai S and Hanaoka F: DNA binding properties of human DNA polymerase $\eta$ : implications for fidelity and polymerase switching of translesion synthesis. Genes Cells 9: 1139-1150, 2004.

21. Ohashi E, Murakumo Y, Kanjo N, Akagi J, Masutani C, Hanaoka $\mathrm{F}$ and Ohmori $\mathrm{H}$ : Interaction of hREV1 with three human Y-family DNA polymerases. Genes Cells 9: 523-531, 2004 .

22. Shimazaki N, Yoshida K, Kobayashi T, Toji S, Tamai T and Koiwai O: Over-expression of human DNA polymerase $\lambda$ in $E$. coli and characterization of the recombinant enzyme. Genes Cells 7: 639-651, 2002.
23. Mizushina Y, Tanaka N, Yagi H, Kurosawa T, Onoue M, Seto H, Horie T, Aoyagi N, Yamaoka M, Matsukage A, Yoshida S and Sakaguchi K: Fatty acids selectively inhibit eukaryotic DNA polymerase activities in vitro. Biochim Biophys Acta 1308: 256-262, 1996.

24. Mizushina Y, Yoshida S, Matsukage A and Sakaguchi K: The inhibitory action of fatty acids on DNA polymerase $\beta$. Biochim Biophys Acta 1336: 509-521, 1997.

25. Ogawa A, Murate T, Suzuki M, Nimura Y and Yoshida S: Lithocholic acid, a putative tumor promoter, inhibits mammalian DNA polymerase $\beta$. Jpn J Cancer Res 89: 1154-1159, 1998.

26. Yonezawa Y, Tsuzuki T, Eitsuka T, Miyazawa T, Hada T, Uryu K, Murakami-Nakai C, Ikawa H, Kuriyama I, Takemura M, Oshige M, Yoshida H, Sakaguchi K and Mizushina Y: Inhibitory effect of conjugated eicosapentaenoic acid on human DNA topoisomerases I and II. Arch Biochem Biophys 435: 197-206, 2005.

27. Nakayama $C$ and Saneyoshi $M$ : Inhibitory effects of 9- $\beta$-D-xylofuranosyladenine 5'-triphosphate on DNA-dependent RNA polymerase I and II from cherry salmon (Oncorhynchus masou). J Biochem (Tokyo) 97: 1385-1389, 1985.

28. Mizushina Y, Dairaku I, Yanaka N, Takeuchi T, Ishimaru C, Sugawara F, Yoshida $\mathrm{H}$ and Kato N: Inhibitory action of polyunsaturated fatty acids on IMP dehydrogenase. Biochimie 89: 581-590, 2007.

29. Soltis DA and Uhlenbeck OC: Isolation and characterization of two mutant forms of T4 polynucleotide kinase. J Biol Chem 257: 11332-11339, 1982

30. Lu BC and Sakaguchi K: An endo-exonuclease from meiotic tissues of the basidiomycete Coprinus cinereus: its purification and characterization. J Biol Chem 266: 21060-21066, 1991.

31. Mizushina Y, Murakami C, Ohta K, Takikawa H, Mori K, Yoshida H, Sugawara F and Sakaguchi K: Selective inhibition of the activities of both eukaryotic DNA polymerases and DNA topoisomerases by elenic acid. Biochem Pharmacol 63: 399-407, 2002.

32. Ishiyama M, Tominaga H, Shiga M, Sasamoto K, Ohkura Y and Ueno K: A combined assay of cell viability and in vitro cytotoxicity with a highly water-soluble tetrazolium salt, neutral red and crystal violet. Biol Pharm Bull 19: 1518-1520, 1996.

33. Isof lavones contents of food. http://www.isoflavones.info/ isoflavones-content.php. Accessed May 15, 2012.

34. Coldham NG, Darby C, Hows M, King LJ, Zhang AQ and Sauer MJ: Comparative metabolism of genistin by human and rat gut microflora: detection and identification of the endproducts of metabolism. Xenobiotica 22: 45-62, 2001.

35. Christian B: Topoisomerase I poisons and suppressors as anticancer drugs. Curr Med Chem 7: 39-58, 2000.

36. Davis TA, Mungunsukh O, Zins S, Day RM and Landauer MR: Genistein induces radioprotection by hematopoietic stem cell quiescence. Int J Radiat Biol 84: 713-726, 2008.

37. Lee $\mathrm{YW}$ and Lee WH: Protective effects of genistein on proinflammatory pathways in human brain microvascular endothelial cells. J Nutr Biochem 19: 819-825, 2008.

38. Okamura S, Sawada Y, Satoh T, Sakamoto H, Saito Y, Sumino H, Takizawa T, Kogure T, Chaichantipyuth C, Higuchi Y, Ishikawa T and Sakamaki T: Pueraria mirifica phytoestrogens improve dyslipidemia in postmenopausal women probably by activating estrogen receptor subtypes. Tohoku J Exp Med 216: 341-351, 2008 